\title{
The relation between joint erosion and forearm bone mineral density in female patient with rheumatoid arthritis
}

\author{
Romatoid Artritli bayan hastalarda eklem erozyonları ile ön kol kemik mineral yoğunluğu \\ arasındaki ilişki
}

\author{
Gülnur Taşçı Bozbaş*, Gülcan Gürer*, Ömer Faruk Şendur*
}

*Physical Medicine and Rehabilitation Department, Adnan Menderes University Medical School, Aydın

\begin{abstract}
Purpose: Rheumatoid arthritis (RA) is a disease that characterized by joint damage including periarticular osteoporosis and focal bone erosion. Despite the fact that periarticular osteoporosis and erosions are known as radiographic hallmarks of RA, there is a lack of data on the relationship between forearm bone loss and radiographic damage. For this reason, we aimed in this study to determine whether there is a relationship between focal erosions and OP in RA patients.

Materials and methods: We evaluated 49 female patients with RA. Anteroposterior hand and foot radiographs and bone mineral density measurement of forearm, hip and lumbar spine with dual x-ray absorptiometry of all patients were taken at simultaneously. Radiographs were analyzed using the Larsen method. Disease activity was evaluated by DAS-28 and functional ability was measured with Health Assessment Questionnaire and Duruöz Hand Index.

Results:Patients had the mean age $53.9 \pm 11.8$ and an average disease duration of $7.9 \pm 5.9$ years. The erosion score was correlated with bone mineral density of forearm, but not with lumbar spine and hip. The disease activity and functional ability were not correlated with Larsen score. Both osteoporosis in all evaluated area and correlations were not affected by the menopause status and disease duration.

Conclusion: Our results demonstrated that bone mineral density of forearm indicate the erosion severity in female patients with RA.
\end{abstract}

Pam Med J 2018;11(1):19-24

Key words: Rheumatoid arthritis, forearm osteoporosis, erosion, dual X-ray absorptiometry

Özet

Amaç: Romatoid artrit (RA) periartiküler osteoporoz ve erozyonların dahil olduğu eklem hasarı ile karakterize bir hastalıktır. Periartiküler osteoporoz ve erozyonlar RA'da iyi bilinen radyolojik bulgular olmasına rağmen, ön kol kemik mineral yoğunluğu ile radyografik hasar arasındaki ilişkiye dair çok az veri mevcuttur. Bu nedenle çalışmamızda RA'da fokal erozyonlar ile osteoporoz arasında ilişki olup olmadığını belirlemeyi amaçladık.

Gereç ve yöntem: Romatoid artritli 49 bayan hasta değerlendirildi. Hastaların tümünün el ve ayak grafileri ile ön kol, lomber ve kalça dual-x ray absorbsiyometri ölçümleri yapıldı. Radyografiler Larsen yöntemi ile değerlendirildi. Hastalık aktivitesi DAS-28 ile ve fonksiyonel durum Genel Sağlık anketi ve Duruöz El İndeksi ile değerlendirildi. Bulgular: Hastaların yaş ortalaması $53.9 \pm 11.8$ ve ortalama hastalık süresi $7.9 \pm 5.9$ yıldı. Erozyon skoru, ön kol kemik mineral dansitesi ile korele iken lomber vertebra ve kalça ile korele değildi. Hastalık aktivitesi ve fonksiyonel durum Larsen skoru ile korele değildi. Gerek değerlendirilen bölgelerdeki osteoporoz, gerekse korelasyonlar menopoz durumu ve hastalık süresinden etkilenmedi.

Sonuç: Sonuçlarımız RA'lı bayan hastalarda ön kol kemik mineral dansitesinin erozyon şiddetini gösterdiğini belirtmektedir.

Pam Tıp Derg 2018;11(1):19-24

Anahtar sözcükler: Romatoid artrit, önkol osteoporoz, erozyon, dual X-ray absorbsiyometri

Gülnur Taşçı Bozbaş

Yazışma Adresi: Physical Medicine and Rehabilitation Department, Adnan Menderes University Medical School, Aydın.

e-mail: gulnurtb@yahoo.com

Gönderilme tarihi: 29.03.2017

Kabul tarihi: 01.08.2017 


\section{Introduction}

Rheumatoid arthritis (RA) is a common chronic inflammatory disease that characterized by joint damage [1]. Joint damage is periarticular osteoporosis and focal bone erosion. In patients with RA, systemic osteoporosis is also seen, as well as periarticular osteoporosis. Osteoporosis is more frequent in patients with RA than the general population [2].

The radiological evaluation was used to assess the joint damage such as periarticular osteoporosis and erosions. The assessment of joint damage with radiograms was used several radiological scoring methods. Since this methods require time and expertise, they are rarely used in everyday practice. In addition, the radiography has many drawbacks, such as the fact that evaluation is depended on the quality of graphy, the early erosion can not be detected and the high radiation exposure. Dual- $X$ ray absorptiometry (DXA) is a technique used to determine the loss of axial and appendicular bone mass in patients with RA [3].

The appendicular bone loss in the distal radius occurs earlier than generalized osteoporosis and may be associated with subsequent progressive joint destruction in patients with RA $[4,5]$.

Despite the fact that periarticular osteoporosis and erosions are known as radiographic hallmarks of $R A$, there is a lack of data on the relationship between forearm bone loss and radiographic damage. For this reason, we aimed to determine whether there is a relationship between focal erosions and OP in RA patients.

\section{Methods}

Fourty-nine females patients who diagnosed to have RA according to 1987 American College of Rheumatology (ACR) criteria were included in the study [6]. The patients with additional diseases which causes osteoporosis and who received antiresorptive treatment in the last one year were excluded from the study. The Institutional Ethics Committee approved the study, and all participants provided their written informed consent to participate in the study. Patient's age, duration of disease, medications and menopause status were recorded. The duration of disease less than 24 months was classified as early RA and longer than 24 months as late RA. History of glucocorticoid usage was questioned and calculated of cumulative dose. Erythrocyte sedimentation rate (ESR), $\mathrm{C}$-reactive protein (CRP), and rheumatoid factor $(\mathrm{RF})$, were evaluated. The disease activity was assessed with disease activity score by using 28-joint Disease Activity Score (DAS-28). DAS28 was calculated on the based of the number of swollen and tender joints over 28 joints, ESR and a general health assessment on a visual analog scala [7]. Functional ability is measured by the Turkish validated Health Assessment Questionnaire (HAQ) and Duruöz Hand Index (DHI) $[8,9]$.

Anteroposterior hand and foot radiographs of all patients were taken at simultaneously. Radiographs were analyzed using the Larsen method, by two rheumatologists. Briefly, 40 joints were scored in each patient from 0 (normal) to 5 (maximal destruction) and then the scores for each patient were summed [10].

Dual-X ray absorptiometry is a gold standart for the measurement of bone mineral density (BMD). BMD measurements of nondominant forearm, total hip, and L1-4 vertebrae were taken by a Hologic Discovery Bone Densitometer (Hologic, Bedford, MA) and t score was used to evaluation. The t-score compares the patient's bone density to the peak bone density of young adults. It is the number of standard deviations of the BMD measurement above or below of young adults of the same sex [1].

SPSS-18 is used for istatistical analyses. The results were expressed as mean \pm standard deviation (SD). Categorical data were analysed with the $\mathrm{x}^{2}$ test. Correlations between the variables were estimated by Spearman's correlation coefficient method. For group comparison, we used t-test for continuous variables if normal distributed and MannWhitney $U$ test if not normal distributed and chi-square test for categorical variables. All $P$ values refer to two sided tests; $P$ values less than 0.05 were considered significant.

\section{Results}

The total study cohort consisted of 49 female RA patients. The mean age was $53.9 \pm 11.8$ years (25-76 years). Average disease duration was $7.9 \pm 5.9$ years ( 10 patients early RA and 39 
patients late RA). Thirteen of the patients were premenopausal and 36 were postmenopausal. All patients were using the DMARDs (synthetic $(87.8 \%)$ and biological (12.2\%). The clinical, laboratory and radiographic findings and cumulative dose of steroid are shown in Table 1.

The results of BMD in patients with pre- and postmenopausal were shown Table 2. Only the lumbar spine $t$ score was significantly different between the two groups $(p<0.05)$. The age and cumulative steroid doses were similar in both groups $(p>0.05)$. There were no statistically differences between the results of BMD in both early and late RA patients (Table 3 ). The age, menopause status and cumulative steroid doses were similar in these groups $(p>0.05)$. The correlation between clinical, laboratory and radiographic measurements with the results of BMD were shown Table 4. It was determined that Larsen score was strongly negative correlated with forearm BMD $(p<0.001)$. This correlation was not affected neither menopause (pre- and post-menopausal respectively r:-0.76, $p<0.05$; r:-0.64, $p<0.001)$ nor disease duration (early and late RA respectively $r:-0.71, p<0.001$; $r:-0,63, p<0.05)$ in RA patients.

Table1. Laboratory and clinical characteristics of the 57 patients who received bone mineral density measurement

\begin{tabular}{|c|c|}
\hline Evaluated Measurements & Mean \pm SD \\
\hline Lumbar spine t score & $-1.72 \pm 1.26$ \\
\hline Lumbar spine z score & $-.67 \pm 1.21$ \\
\hline Femur t score & $-1.43 \pm .99$ \\
\hline Femur z score & $-.61 \pm .97$ \\
\hline Forearm $\mathrm{t}$ score & $-1.95 \pm 1.66$ \\
\hline Forearm z score & $-.87 \pm 1.47$ \\
\hline Larsen score & $18.04 \pm 18.75$ \\
\hline DAS28 & $3.88 \pm 1.14$ \\
\hline ESR & $44.46 \pm 19.89$ \\
\hline CRP & $18.07 \pm 33.94$ \\
\hline RF & $85.23 \pm 99.6$ \\
\hline $\mathrm{HAQ}$ & $14.54 \pm 10.22$ \\
\hline $\mathrm{DHI}$ & $16.18 \pm 14.06$ \\
\hline Cumulative dose of steroid & $5.48 \pm 3.82$ \\
\hline
\end{tabular}

Table 2. Prevalence of osteoporosis and osteopenia

\begin{tabular}{lcccccc}
\hline & \multicolumn{2}{c}{ Normal } & \multicolumn{2}{c}{ Osteopenia } & \multicolumn{2}{c}{ Osteoporosis } \\
\hline & $\mathrm{n}$ & $\%$ & $\mathrm{n}$ & $\%$ & $\mathrm{n}$ & $\%$ \\
Lumbar spine (L1-4) & 17 & $29.8 \%$ & 23 & $40.4 \%$ & 17 & $29.8 \%$ \\
Total Hip & 23 & $40.4 \%$ & 22 & $38.6 \%$ & 12 & $21.1 \%$ \\
Forearm & 13 & $22.8 \%$ & 25 & $43.9 \%$ & 19 & $33.3 \%$ \\
\hline
\end{tabular}


Table 3. Comparison of the bone mineral density of patients using biological and synthetic diseasemodifiying antirheumatic drugs (DMARDs) with early and late rheumatoid arthritis (RA)

\begin{tabular}{lccc}
\hline & $\begin{array}{c}\text { Early RA } \\
(\mathrm{n}: 11)\end{array}$ & $\begin{array}{c}\text { Late RA } \\
(\mathrm{n}: 46)\end{array}$ & $\mathrm{p}$ \\
\hline Lumbar spine t score & $-1.89 \pm 0.91$ & $-1.68 \pm 1.33$ & $* *$ \\
Lumbar spine z score & $-0.74 \pm 0.73$ & $-0.66 \pm 1.31$ & $* *$ \\
Femur t score & $-1.41 \pm 0.98$ & $-1.44 \pm 0.99$ & $* *$ \\
Femur z score & $-0.58 \pm 0.66$ & $-0.62 \pm 1.03$ & $* *$ \\
Forearm t score & $-1.89 \pm 1.88$ & $-1.96 \pm 1.62$ & $* *$ \\
Forearm z score & $-0.77 \pm 1.25$ & $-0.89 \pm 1.52$ & $* *$ \\
\hline & Synthetic DMARDs & Biological DMARDs \\
(n:51) & $-1.42 \pm 0.64$ & $* *$ \\
\hline Lumbar spine t score & $-1.75 \pm 1.31$ & $-0.89 \pm 0,79$ & $* *$ \\
Lumbar spine z score & $-0.65 \pm 1.25$ & $-1.63 \pm 0.72$ & $* *$ \\
Femur t score & $-1.41 \pm 1.02$ & $-0.96 \pm 0.79$ & $* *$ \\
Femur z score & $-0.57 \pm 0.99$ & $-1.04 \pm 1.05$ & $* *$ \\
Forearm t score & $-2.05 \pm 0.69$ & $-0.42 \pm 1.18$ & \\
Forearm z score & $-0.92 \pm 1.50$ & & \\
\hline$* *$ p $>0.05$ level (2-tailed). & & & \\
\hline
\end{tabular}

Table 4. Clinical, laboratory and radiographic measurements correlation with BMD

\begin{tabular}{lccc}
\hline & BMD, lumbar spine & BMD, total hip & BMD, forearm \\
\hline Larsen score & $r$ & $r$ & $-.49^{* *}$ \\
DAS28 & -.17 & $-.33^{*}$ & -.23 \\
DHI & -.10 & -.19 & -.19 \\
HAQ & -.21 & -.17 & -.23 \\
Usage of steroid & -.15 & -.22 & -.02 \\
Cumulative steroid dose & -.03 & -.04 & -.12 \\
CRP & -.06 & -.16 & -.09 \\
ESR & -.11 & -.04 & -.20 \\
RF & -.03 & -.11 & $.34^{*}$ \\
\hline
\end{tabular}

(BMD: Bone mineral density; DAS28: Disease activiy score28; ESR: eritrosit sedimentation rate; CRP: C-reactive protein; RF: Rheumatoid factor; HAQ: Health Assessment Questionnaire; DHI: Duruöz Hand Index) * Correlation is significant at the 0.05 level (2-tailed).

**. Correlation is significant at the 0.01 level (2-tailed).

\section{Discussion}

Rheumatoid arthritis is the most common form of inflammatory arthritis in adults. The skeletal system is a major target organ and is characterized by focal bone erosions, local and systemic osteoporosis [1,2,11]. Radiological scoring methods to evaluated the erosion severity is rarely used in daily practice of a physicians. Wheras, the determination of severity in erosions is very important to follow the disease and evaluation in seriousness [10]. In our study, we determined that forearm BMD was correlated with erosion score. Therefore, we think that the forearm BMD may be a subjective and reliable method of assesing the erosion severity. Similar to our study, Desai et al. [18] had investigated the relation between osteoporosis and erosions. But, in their study, BMD of the forearm and hand, which is the most common areas for erosions, have not been evaluated. Previous studies have shown that hand BMD correlates with the severity of radiographic erosions [12-14]. However, in RA patients, the severe hand deformity can lead to change of hand position in DXA, thus causes an incorrect evaluation of the BMD. Also reference values of the hand BMD in ethnic groups is 
not determined [3]. So it is more precious to evaluate the BMD of forearm instead of the hand in RA patients, as in our study. This relationship may be due to focal erosions and OP may be occured the similar inflammatory cascade. The inflammatory cytokines, such as tumor necrosis factor- $\alpha$ and RANKL, play important roles in both processes. The osteoprotogerin that stimulated by these proinflammatory cytokines causes erosion and osteoporosis via stimulating formation and activation of osteoclasts [15]. Lumbar spine and hip joint is less affected by RA-induced inflammation. For this reason erosive changes rarely ocur [1]. On the other hand, BMD measurements of lumbar vertebrae and hip may be erroneous results depending on degenerative joint disease, especially in older patients as in our study. It may be due to these factors that we have not determinated the relationship between BMD of lumbar vertebrae and hip and erosion severity.

In early RA, periarticular osteoporosis may occur before the erosions visible [16]. For this reason the relationship between hand or forearm bone loss and erosions can be expected and have also been shown in various studies $[12,16,17]$. Whereas in our study, this relationship was not only early but also in the late RA. In this case, we thought it might be that the forearm BMD is an indicator of erosion severity regardless of the duration of RA.

Menopause is an important risk factor in the development of osteoporosis [18]. However in our study, we determined that only lumbar vertebrae BMD is affected by menopause, there is no change in others. This result may be due to the periarticular bone loss occured especially in patients with RA [5,19-21]. The correlation between forearm BMD and erosion score was also present both premenopausal and postmenopausal RA patients.

Glucocorticoids supress of inflammation in RA and reduce the rate of joint destructions as seen on radiography, but they may cause osteoporosis [22]. On the other hand, RA-induced osteoporosis is caused by systemic inflammation [23]. For this reason immunsuppressive treatment, including glucocorticoids, can prevent disease related bone loss in RA [22-24]. We also determined that osteoporosis was not affected by the cumulative dose of glucocorticoids in RA patients, similar to previous studies $[25,26]$. We did not find the correlation between the bone loss and RF, disease activity, and disability, as in some previous studies [13,27-29].

In conclusion, our study demonstrated that forearm BMD measurement indicate the erosion severity in female patients with RA. The monitoring of erosion severity is very important especially in follow-up of these patients. For this reason, when considering the limitations of radiographic evaluation of erosions, we believe that forearm BMD can be used instead of radiography in following the disease.

Conflict of interest: The authors declared that there was no conflict of interest.

\section{References}

1) Solomon $\mathrm{DH}$, Finkelstein JS, Shadick $\mathrm{N}$, et al. The relationship between focal erosions and generalized osteoporosis in postmenopausal women with rheumatoid arthritis. Arthritis Rheum 2009;60:16241631.

2) Munro R, Capell $H$. Prevalence of low body mass in rheumatoid arthritis: association with the acute phase response. Ann Rheum Dis 1997;56:326-329.

3) Kilic G, Ozgocmen S. Hand bone mass in rheumatoid arthritis: a review of the literature. World J Orthop 2015;18:106-107.

4) Devlin J, Lilley J, Gough A, et al. Clinical associations of dual-energy X-ray absorptiometry measurement of hand bone mass in rheumatoid arthritis. Br J Rheumatol 1996;35:1256-1262.

5) Haugeberg G, Green MJ, Quinn MA, et al. Hand bone loss in early undifferentiated arthritis: evaluating bone mineral density loss before the development of rheumatoid arthritis. Ann Rheum Dis 2006;65:736-740.

6) Arnett FC, Edworthy SM, Bloch DA, et al. The American Rheumatism Association 1987 revised criteria for the classification of rheumatoid arthritis. Arhritis Rheum 1988;31:315-324.

7) Fransen J, Stucki G, van Riel P.L.C.M Rheumatoid arthritis measures: Disease Activity Score (DAS), Disease Activity Score-28 (DAS28), Rapid Assessment of Disease Activity in Rheumatology (RADAR), and Rheumatoid Arthritis Disease Activity Index (RADAI). Arthritis Rheum 2003;49:214-224.

8) Küçükdeveci $A$, Sahin $H$, Ataman $S$, Griffiths $B$, Tennant A. Issues in cross-cultural validity: Example from the adaptation, reliability, and validity testing of a Turkish version of the Stanford Health Assessment Questionnaire. Arthritis Rheum 2004;51:14-19.

9) Duruöz MT, Poiraudeau S, Fermanian J, et al. Development and validation of a rheumatoid hand functional disability scale that assesses functional handicap. J Rheumatol 1996;23:1167-1172. 
10) Larsen A. How to apply Larsen score in evaluating radiographs of rheumatoid arthritis in long-term studies. J Rheumatol 1995;22:1974-1975.

11) Cooper C, Coupland C, Mitchell M. Rheumatoid arthritis, corticosteroid therapy and hip fracture. Ann Rheum Dis 1995;54:49-52.

12) Daragon A, Krzanowska K, Vittecoq $O$, et al. Prospective X-ray densitometry and ultrasonography study of the hand bones of patients with rheumatoid arthritis of recent onset. Joint Bone Spine 2001;68:3442.

13) Dogu B, Kuran B, Yilmaz F, et al. Is hand bone mineral density a marker for hand function in patients with established rheumatoid arthritis? The correlation among bone mineral density of the hand, radiological findings and hand function. Clin Rheum 2013;32:11771183.

14) Jensen $T$, Klarlund M, Hansen M, et al. Bone loss in unclassified polyarthritis and early rheumatoid arthritis is better detected by digital $x$ ray radiogrammetry than dual $x$ ray absorptiometry: relationship with disease activity and radiographic outcome. Ann Rheum Dis 2004;63:15-22.

15) Walsh NC, Gravallese EM. Bone loss in inflammatory arthritis: mechanisms and treatment strategies. Curr Opin Rheumatol 2004;16:419-427.

16) Hoff M, Haugeberg G. Using hand bone mass measurements to assess progression of rheumatoid arthritis. Ther Adv Musculoskelet Dis. 2010;2:79-87.

17) Haugeberg G, Green MJ, Conaghan PG, et al. Hand bone densitometry: a more sensitive standart for the assessment of early bone damage in rheumatoid arthritis. Ann Rheum Dis 2007;66:1513-1517

18) Desai SP, Gravallese EM, Shadick NA, et al. Hand bone mineral density is associated with both total hip and lumbar spine bone mineral density in post-menopausal women with RA. Rheumatology 2010;49:513-519.

19) Deodhar AA, Brabyn J, Jones PW, Davis MJ, Woolf $A D$. Longitudinal study of hand bone densitometry in rheumatoid arthritis. Arthritis Rheum 1995;38:12041210.

20) Murphy E, Roux-Lombard P, Rooney T, Fitzgerald O, Dayer JM, Bresnihan B. Serum levels of tissue inhibitor of metalloproteinase-1 and periarticular bone loss in early rheumatoid arthritis. Clin Rheumatol 2009;28:285-291.

21) Deodhar AA, Brabyn J, Pande I, Scott DL, Woolf AD. Hand bone densitometry in rheumatoid arthritis, a five year longitudinal study: an outcome measure and a prognostic marker. Ann Rheum Dis 2003;62:767-770.

22) Haugeberg G, Strand A, Kvien TK, Kirwan JR. Reduced loss of hand bone density with prednisolone in early rheumatoid arthritis: results from a randomized placebocontrolled trial. Arch Intern Med 2005;165:1293-1297.
23) Haugeberg G, Helgetveit KB, Førre $\varnothing$, Garen T, Sommerseth H, Prøven A. Generalized bone loss in early rheumatoid arthritis patients followed for ten years in the biologic treatment era. BMC Musculoskelet Disord 2014;15:289-298.

24) Haugeberg G, Conaghan PG, Quinn M, Emery P. Bone loss in patients with active early rheumatoid arthritis: infliximab and methotrexate compared with methotrexate treatment alone. Explorative analysis from a 12-month randomised, double-blind, placebocontrolled study. Ann Rheum Dis 2009;68:1898-1901.

25) Sivas F, Barça N, Önder N, Ozoran K. The relation between joint erosion and generalized osteoporosis and disease activity in patients with rheumatoid arthritis Rheumatol Int 2006;26:896-899.

26) Van Staa TP, Leufkens HG, Abenhaim L, Zhang B, Cooper C. Oral corticosteroids and fracture risk: relationship to daily and cumulative doses. Rheumatology (Oxford) 2000;39:1383-1389.

27) Desai SP, Gravallese EM, Shadick NA, et al. Hand bone mineral density is associated with both total hip and lumbar spine bone mineral density in postmenopausal women with RA. Rheumatology (Oxford) 2010;49:513-519

28) Njeh CF, Boivin CM, Gough A, et al. Evaluation of finger ultrasound in the assessment of bone status with application of rheumatoid arthritis. Osteoporos Int 1999;9:82-90.

29) Deodhar AA, Brabyn J, Jones PW, Davis MJ, Woolf $A D$. Measurement of hand bone mineral content by dual energy $\mathrm{X}$-ray absorptiometry: development of the method, and its application in normal volunteers and in patients with rheumatoid arthritis. Ann Rheum Dis 1994;53:685-690. 